\title{
Shear modulus and damping ratio of a nonplastic silt at large shear strains
}

\author{
Alper Sezer, ${ }^{1, *}$ Eyyub Karakan ${ }^{2}$, Nazar Tanrinian ${ }^{3}$ \\ ${ }^{1}$ Ege University, Department of Civil Engineering, 35100, Izmir, Turkey \\ ${ }^{2}$ Kilis 7 Aralik University, Department of Civil Engineering, Kilis, Turkey \\ ${ }^{3}$ LBA Design \& Construction, Istanbul, Turkey
}

\begin{abstract}
Site response analyses and solution of dynamic soil-structure interaction problems need determination of variation of shear modulus and damping ratio with shear strain. Since many studies in literature concern evaluation of behavior of sands and silty sands, a series of cyclic triaxial tests were performed to determine the variation of shear modulus and damping ratio of a nonplastic silt with shear strain. Stress controlled cyclic triaxial tests on silt specimens of initial relative densities ranging among $30 \%, 50 \%$ and $70 \%$ were performed. Tests were carried out on identical samples under different CSR levels, and the confining pressure was selected as $100 \mathrm{kPa}$. Variation of shear modulus and damping ratio of silts with cyclic stress ratio amplitude, relative density and number of cycles were investigated. It was understood that soil relative density and cyclic stress ratio amplitude has a significant influence on shear modulus and damping ratio of silts. It was also observed that, as the cyclic stress ratio amplitude is increased, greater shear modulus and lower damping ratio values were obtained.
\end{abstract}

\section{Introduction}

Site response analysis is necessary for assessment of the behavior of soils subjected to seismic action, which is also advised by Eurocode 8 and the New Turkish Building Code for Earthquake Resilience, which went into effect by $1^{\text {st }}$ of January, 2019. Along with site response analysis, solution of soil-structure interaction problems necessitate two parameters as inputs, which are vital for evaluation of the seismic response-shear modulus and damping ratio. The Young modulus $(E)$ is defined as the slope of a secant line that connects the extreme points on a hysteresis loop at a given shear strain, as shown in Figure 1 [1]. From cyclic triaxial test results, a hysteresis loop is obtained by plotting the deviator stress $\left(\sigma_{d}\right)$ versus axial strain $(\varepsilon)$. In equations from 1 to 3 , shear modulus $(G)$ calculation procedure is summarized. It is clear that, as the cyclic strain amplitude increases, the shear modulus decreases.

$$
\begin{gathered}
\gamma=(1+\mu) * \varepsilon \\
E=\frac{\sigma_{d \max }}{\epsilon_{\max }} \\
G=\frac{E}{2(1+\mu)}
\end{gathered}
$$

where, $G$ is the shear modulus, $\gamma$ is the shear strain and $\mu$ is the Poisson's ratio that may be assumed as 0.5 for saturated specimen tested under undrained conditions [1]. Initial stiffness of soil, which is known as the maximum shear modulus is also obtained by use of following formulation:

$$
G_{0}=\rho V_{s}^{2}
$$

where $G_{0}, \rho$ and $V_{s}$ are in terms of $\mathrm{Pa}, \mathrm{kg} / \mathrm{m}^{3}$ and $\mathrm{m} / \mathrm{s}$; respectively. As the cyclic shear strain is increased, the rigidity of the soil is decreased due to relative particle slippage and rearrangement. Normalized shear modulus $\left(G / G_{0}\right)$ at a certain strain rate is defined as the ratio of shear modulii in a certain level and its initial value. Degradation in soil stiffness is quantified by decrease in shear modulus $(G)$ or normalized shear modulus $\left(G / G_{0}\right)$, after a certain shear strain level $[1,2]$. On the other hand, damping ratio $(D)$ is a descriptor of the dissipation of energy during shearing, which is calculated by:

$$
D=\frac{W_{D}}{4 \pi W_{S}}
$$

where $W_{D}$ and $W_{S}$ are amounts of energy dissipated in a cycle of loading and greatest amount of strain energy stored during that cycle of loading, respectively [3]. From Figure $1, W_{D}$ and $W_{S}$ stand for measures of dissipated energy $\left(A_{L}\right)$ and elastic strain energy $\left(A_{T}\right)$ during one cycle, which are hatched with dots and vertical lines, respectively.

Studies in the past concentrate on the various parameters affecting on shear modulus and damping ratio of such as cyclic strain amplitudes [4-5], effective confining pressures, soil types [6-7], plasticity index [7-8], density [9], frequency of loading, number of loading cycles [9-

\footnotetext{
* Corresponding author: alper.sezer@ege.edu.tr
} 
10], overconsolidation ratio [9], degree of saturation and grain characteristics on the dynamic properties of soils [10-12]. Seed and Idriss (1970) [4] suggested that normalized shear modulus $\left(G / G_{\max }\right)$ of silty soil is generally higher than that of saturated sand while its damping ratio is lower than that of saturated clay. However, majority of the existing studies focus on testing sands or silty sands - fewer studies are performed on silts due to problems in specimen preparation, saturation and testing. In this regard, El Takch et al. [3] carried out cyclic ring shear and bender element tests to evaluate the behavior of silts and sandy silts. The authors stress that, although shear modulus increases and damping ratio decreases with shear strain, this behavior is not valid beyond a shear strain level of 0.01. Fang et al. [13] performed stress controlled simple shear tests on undisturbed silt specimens obtained from 6-10 m depths of Greater Shangai region in China. The authors emphasize that the shear modulus of silts are between those of sands and clays. Chen et al. [14] carried our free vibration column tests to compare the differences among marine and continental deposited soils, noting down differences for silt and fine sands. El Mosallamy et al. [15] carried out oedometer and resonant column tests on a loess soil. Presenting the results in detail, the authors underline that $G_{\max }$ is positively affected from increases in confining pressure and relative density, but negatively affected from silt content. Contrary to these, the authors noted down unremarkable changes in damping properties due to silt content and water content, underlining a slight reduction by increases in confining pressure and relative density. On the other hand, Hsiao and Phan [16] carried out an extensive study to evaluate the dynamic behavior of silt-sand mixtures. The authors revealed that increase in silt content causes increase in maximum shear modulus increased. Although the CSR is initially decreased by increasing silt content, after a certain threshold silt content, this behavior is reversed.

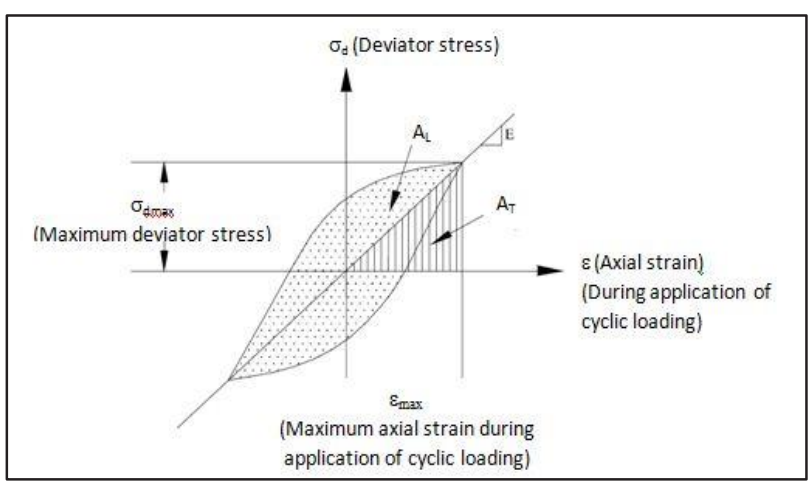

Fig. 1. Hysteretic stress-strain relationship

In this study, change in shear modulus and damping ratio of a nonplastic silt was investigated within an experimental framework. In this scope, effects of cyclic stress ratio (CSR) amplitude, relative density and number of cycles on shear modulus and damping ratio of silts were investigated.

\section{Materials and Methods}

\subsection{Properties of silt}

Obtained from ESAN company, nonplastic silt used in this study has a specific gravity of 2.65 . The grain size distribution of silt is given in Figure 2. The maximum and minimum void ratios according to Method 1A of ASTM4253 standard were determined as 1.352 and 0.894 , respectively [17].

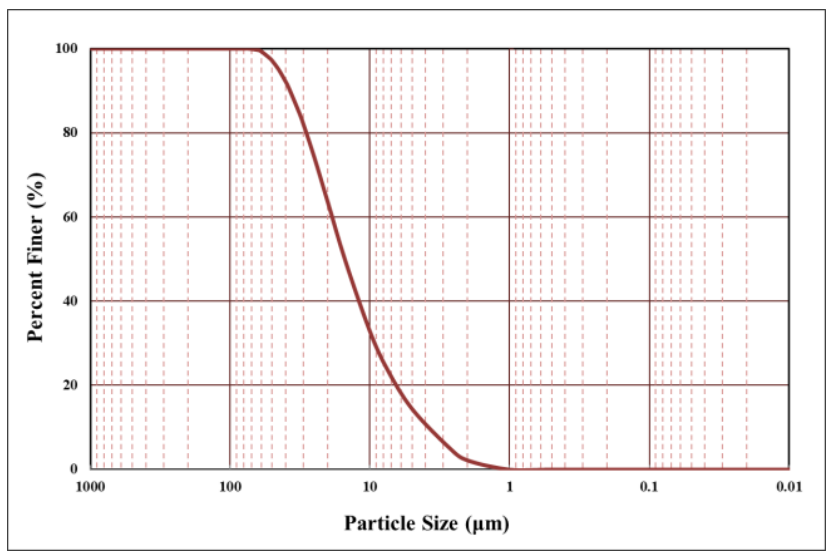

Fig. 2. Grain size distribution of nonplastic silt

\subsection{Cyclic triaxial tests}

Using a Seiken DTC-S367 cyclic triaxial system, stress controlled cyclic triaxial tests were performed according to JGS 0542-2000 [1] by application of different cyclic stress ratios on a non-plastic silt, prepared at 3 different initial relative densities $30 \%, 50 \%$ and $70 \%$. A constant effective confining pressure is applied $(100 \mathrm{kPa})$ and frequency of loading was $0.1 \mathrm{~Hz}$. A total of 30 tests were performed. The tests were performed on $50 \mathrm{~mm} \times 100 \mathrm{~mm}$ specimens. The specimens were prepared in accordance with JGS 0520-2000 [18] and subsequently tested according to JGS 0541-2000 [19]. A porous stone and filter paper were placed on pedestal. Later, a cylindrical rubber membrane was secured to pedestal with O-rings. A split mold was placed on the lower plate of the triaxial cell, vacuum was supplied to the mold and upper part of the membrane was secured. Silt was carefully poured in mold and, specimen was wet-compacted using a wooden rod until the specimen height corresponding to a certain relative density was achieved. After clearing off the top of specimen a filter paper and a porous stone were placed at the top. Rubber membrane was slipped to cover the specimen cap. Self-standing specimen was ensured by application of confining pressure. Carbon dioxide and subsequently de-aired water were percolated through the specimen. The specimen was saturated by back pressure application. After reaching to a Skempton's pore water 
pressure parameter $(B)$ above $96 \%$, consolidation process under a confining pressure of $100 \mathrm{kPa}$ was initiated. While holding the back-pressure constant, cell pressure is gradually increased until the difference between the cell pressure and the back pressure equals the desired consolidation pressure. The next phase was application of undrained cyclic loading, and specimens were loaded up to 20 cycles- testing were stopped as the double amplitude axial strain exceeded 5\%. Excess pore water pressure, cyclic axial strain and cyclic deviatoric stresses were continuously recorded during cyclic loading. After the end of loading, drainage valves are opened to measure post-cyclic volume change. Further details of testing procedure can be found elsewhere [20]. A summary of results of testing program is given in Table 1.

Table 1. Summary of testing program

\begin{tabular}{|c|c|c|c|c|c|c|c|c|c|c|c|c|}
\hline Test \# & $\begin{array}{l}\text { Relative } \\
\text { Density }\end{array}$ & $\begin{array}{l}\text { Initial } \\
\text { void } \\
\text { ratio, e }\end{array}$ & $\begin{array}{c}\text { Void ratio after } \\
\text { consolidation } \\
\left(\mathrm{e}_{\mathrm{c}}\right)\end{array}$ & \begin{tabular}{|c|} 
Relative \\
density after \\
consolidation \\
$\left(\operatorname{Dr}_{\mathrm{c}}(\%)\right)$
\end{tabular} & $\begin{array}{c}\text { Skempton } \\
\text { value, } \mathrm{B}\end{array}$ & $\begin{array}{r}\text { Consolidation } \\
\text { Pressure }(\mathrm{kPa})\end{array}$ & $\begin{array}{l}\text { Cyclic } \\
\text { Stress } \\
(\mathrm{kPa})\end{array}$ & CSR & $\begin{array}{c}\text { Number of } \\
\text { Cycles }\end{array}$ & $\begin{array}{l}\text { PWP } \\
\text { (Max) }\end{array}$ & $\begin{array}{c}\text { Cyclic } \\
\text { Axial } \\
\text { Strain } \\
\left(\varepsilon_{\mathrm{a}}\right) \mathrm{sa}(\%)\end{array}$ & $\begin{array}{c}\text { Double } \\
\text { amplitude of } \\
\text { axial strain } \\
(\%)\end{array}$ \\
\hline 1 & 70 & 1.0314 & 1.015 & 73.533 & 0.970 & 97 & 4.390 & 0.023 & 20 & 1.55 & 0.013 & 0.027 \\
\hline 2 & 70 & 1.0314 & 1.016 & 73.313 & 0.990 & 97 & 9.320 & 0.048 & 20 & 5.72 & 0.019 & 0.039 \\
\hline 3 & 70 & 1.0314 & 1.017 & 73.232 & 1.000 & 99.5 & 13.764 & 0.069 & 20 & 8.84 & 0.058 & 0.116 \\
\hline 4 & 70 & 1.0314 & 1.025 & 71.384 & 0.996 & 96 & 17.235 & 0.090 & 20 & 22.71 & 0.127 & 0.254 \\
\hline 5 & 70 & 1.0314 & 1.024 & 71.604 & 0.891 & 99 & 26.617 & 0.166 & 20 & 50.76 & 0.219 & 0.438 \\
\hline 6 & 70 & 1.0314 & 1.028 & 70.680 & 0.976 & 94 & 29.002 & 0.154 & 6 & 100.00 & 11.060 & 22.120 \\
\hline 7 & 70 & 1.0314 & 1.022 & 72.132 & 0.935 & 93.2 & 34.260 & 0.184 & 3 & 100.00 & 14.565 & 29.130 \\
\hline 8 & 70 & 1.0314 & 1.015 & 73.584 & 0.985 & 97.2 & 37.731 & 0.194 & 1 & 100.00 & 11.962 & 23.924 \\
\hline 9 & 70 & 1.0314 & 1.023 & 71.912 & 1.000 & 97.2 & 40.313 & 0.207 & 0.8 & 100.00 & 18.053 & 36.106 \\
\hline 10 & 70 & 1.0314 & 1.016 & 73.452 & 0.999 & 98.4 & 41.261 & 0.210 & 0.5 & 100.00 & 18.046 & 36.092 \\
\hline 11 & 50 & 1.123 & 1.106 & 53.701 & 1.000 & 99.2 & 2.213 & 0.011 & 20 & 1.31 & 0.011 & 0.022 \\
\hline 12 & 50 & 1.123 & 1.108 & 53.241 & 1.000 & 99 & 4.661 & 0.024 & 20 & 3.03 & 0.015 & 0.030 \\
\hline 13 & 50 & 1.123 & 1.109 & 53.011 & 1.000 & 98.3 & 9.463 & 0.048 & 20 & 6.00 & 0.031 & 0.061 \\
\hline 14 & 50 & 1.123 & 1.106 & 53.701 & 1.000 & 99.3 & 12.250 & 0.062 & 20 & 9.06 & 0.042 & 0.083 \\
\hline 15 & 50 & 1.123 & 1.107 & 53.517 & 0.903 & 99 & 13.816 & 0.070 & 20 & 8.49 & 0.056 & 0.113 \\
\hline 16 & 50 & 1.123 & 1.107 & 53.425 & 1.006 & 99 & 18.166 & 0.092 & 20 & 26.34 & 0.147 & 0.294 \\
\hline 17 & 50 & 1.123 & 1.110 & 52.735 & 1.000 & 99 & 23.635 & 0.119 & 18 & 100.00 & 7.109 & 14.218 \\
\hline 18 & 50 & 1.123 & 1.111 & 52.551 & 1.000 & 99 & 29.555 & 0.149 & 7 & 100.00 & 11.616 & 23.232 \\
\hline 19 & 50 & 1.123 & 1.112 & 52.321 & 0.930 & 99 & 32.258 & 0.163 & 5 & 100.00 & 12.733 & 25.466 \\
\hline 20 & 50 & 1.123 & 1.115 & 51.678 & 1.000 & 100.9 & 36.954 & 0.183 & 2 & 100.03 & 11.534 & 23.067 \\
\hline 21 & 30 & 1.2146 & 1.197 & 33.889 & 0.970 & 100 & 2.030 & 0.010 & 20 & 1.20 & 0.012 & 0.024 \\
\hline 22 & 30 & 1.2146 & 1.206 & 31.961 & 0.965 & 99.8 & 4.457 & 0.022 & 20 & 2.30 & 0.020 & 0.041 \\
\hline 23 & 30 & 1.2146 & 1.204 & 32.347 & 0.975 & 99.8 & 8.925 & 0.045 & 20 & 4.11 & 0.031 & 0.062 \\
\hline 24 & 30 & 1.2146 & 1.199 & 33.504 & 1.000 & 99.9 & 11.369 & 0.057 & 20 & 6.81 & 0.046 & 0.092 \\
\hline 25 & 30 & 1.2146 & 1.199 & 33.409 & 0.984 & 99.9 & 13.518 & 0.068 & 20 & 9.61 & 0.072 & 0.145 \\
\hline 26 & 30 & 1.2146 & 1.203 & 32.450 & 0.956 & 100 & 17.424 & 0.087 & 20 & 34.60 & 0.188 & 0.376 \\
\hline 27 & 30 & 1.2146 & 1.197 & 33.889 & 0.981 & 99.7 & 20.774 & 0.104 & 15 & 100.00 & 1.310 & 2.620 \\
\hline 28 & 30 & 1.2146 & 1.206 & 31.970 & 0.980 & 99.7 & 24.523 & 0.123 & 3 & 100.00 & 4.963 & 9.925 \\
\hline 29 & 30 & 1.2146 & 1.198 & 33.696 & 0.939 & 99.8 & 30.810 & 0.154 & 2 & 92.79 & 4.250 & 8.500 \\
\hline 30 & 30 & 1.2146 & 1.200 & 33.118 & 1.000 & 99.9 & 33.208 & 0.166 & 1 & 97.70 & 3.357 & 6.713 \\
\hline
\end{tabular}




\section{Evaluation of results}

A typical test result is for a silt specimen with a relative density $\left(D_{r}\right)$ of $50 \%$ is given in Figure 3. Deviatoric stressaxial strain plot for the first cycle of loading was obtained from stress controlled cyclic triaxial test where $\mathrm{CSR}=0.119$. The test was conducted at a frequency of 0.1 $\mathrm{Hz}$ and the data was collected at every 5 millisecond: i.e. 100 points for one cycle. Figure 4 shows shear stress versus shear strain plot, which was calculated by use of data in Figure 3.

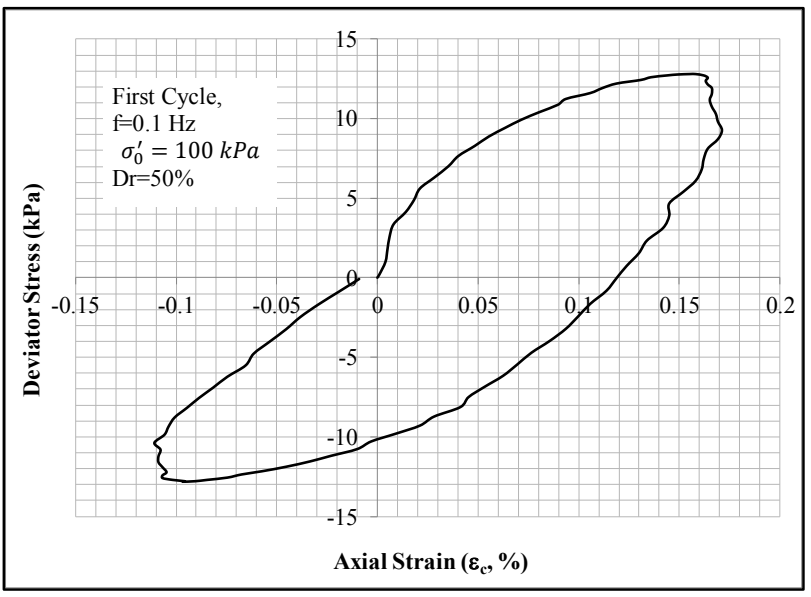

Fig. 3. Deviatoric stress vs. axial strain relationship

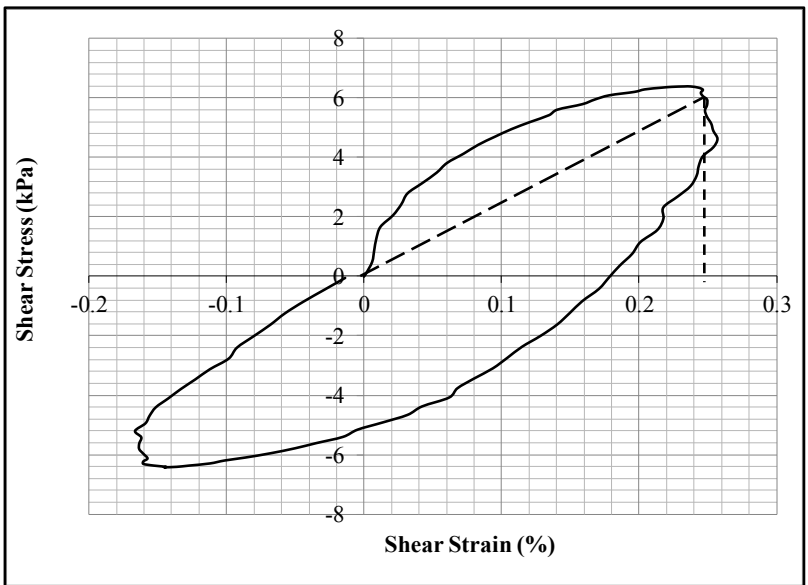

Fig. 4. Shear stress vs. shear strain relationship

Figures $5 \mathrm{a}$ to $5 \mathrm{c}$ demonstrate the effects of cyclic stress ratio. In these figures, variation in shear modulus $(G)$ at large shear strain are shown for specimens prepared at initial relative densities among $30 \%, 50 \%$ and $70 \%$. The shear modulus $(G)$ values given in figures are in agreement with those reported by Maheshwari and Patel [11]. In addition, for specimens of same relative density, as the cyclic stress ratio (CSR) increases, decrease in shear modulus and a corresponding increase in shear strain is observed. For a constant relative density level, increase in CSR shows that silt will reach higher deformation levels at lower number of cycles of loading.
Besides, it is evident that as the shear strain increases, the shear modulus decreases for a constant cyclic stress ratio. The trend observed in results is similar to that for silt reported by Maheshwari et.al. [10] and Muley et.al. [12]. Variation of cyclic stress ratio had a significant effect on shear modulus $(G)$ and shear strain $(\gamma)$ (Figure 5a-c). From Figure $5 \mathrm{a}$, it was revealed that the maximum value of shear modulus is obtained at $\mathrm{CSR}=0.011$ at all shear strains of specimens of $30 \%$ relative density. Figures $5 \mathrm{~b}$ and $5 \mathrm{c}$ approve the above-mentioned result, at $50 \%$ and $70 \%$ relative density levels.
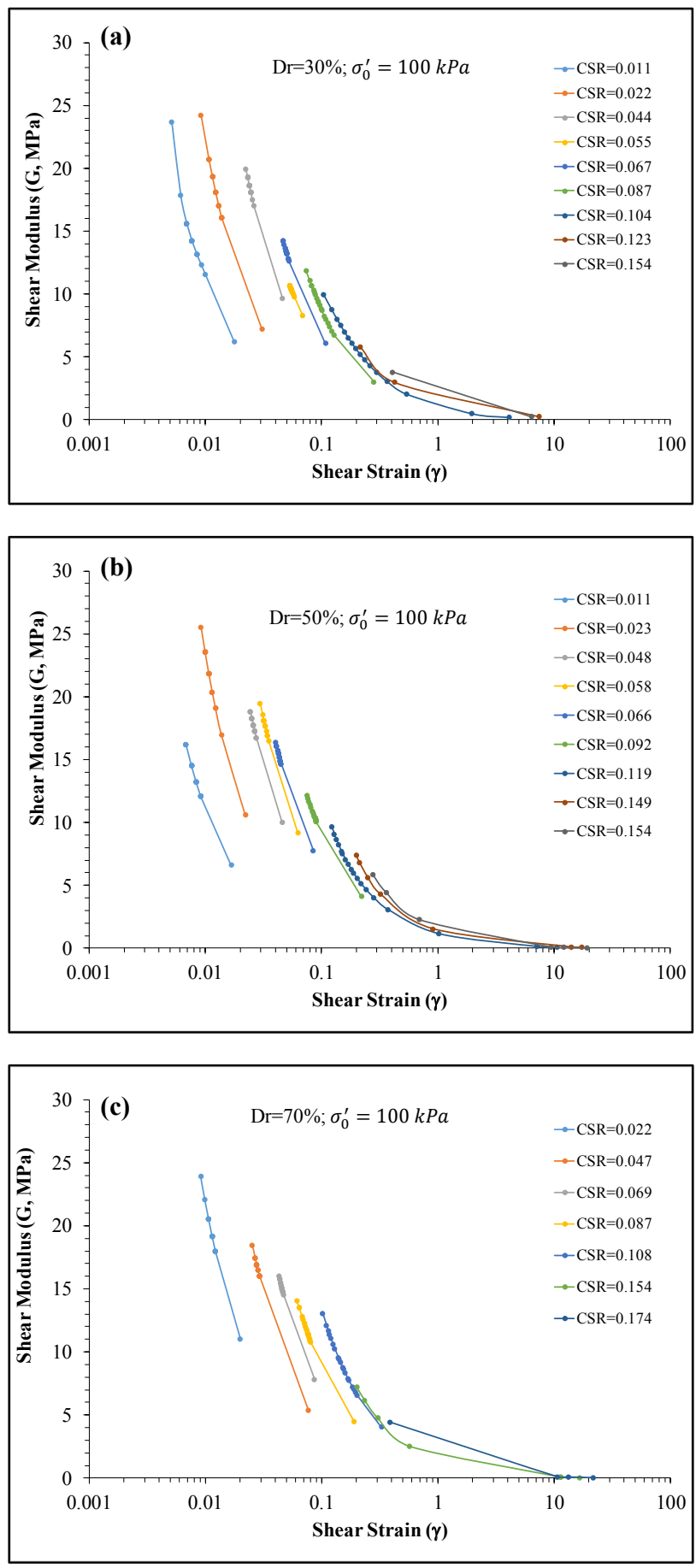

Fig. 5. Influence of cyclic stress ratio on shear modulus-shear strain relationship a) $D_{r}=30 \%$ b) $D_{r}=50 \%$ c) a) $D_{r}=70 \%$ 
To investigate the effects of relative density, the results were compared for relative densities of $30 \%, 50 \%$ and $70 \%$. Table 1 includes information concerning relative densities and void ratios before and after consolidation stage. As can be seen from Table 1, maximum postconsolidation relative density values corresponding to initial relative densities of $30 \%, 50 \%$ and $70 \%$ are calculated as $33.9 \%, 53.7 \%$ and $73.6 \%$, respectively. Furthermore, for evaluation of the effect of relative density; shear moduli and shear strains were compared at small and large cyclic stress ratio (CSR) values (Figure 6). As can be derived from Figure 6, for both small and large CSR values, greater changes in shear moduli were observed at $30 \%$ relative density and rate of this change was decreased as the relative density was increased, respectively. At $\mathrm{CSR}=0.022$, shear moduli were obtained between $27 \mathrm{MPa}$ to $8 \mathrm{MPa}$ while corresponding shear strain values were at 0.009 to 0.03 . However, in the case of large CSR values, maximum shear modulus was about to $7 \mathrm{MPa}$ and shear strain values were changed between 0.2 to $10 \%$. These values prove that large deformation levels were reached.

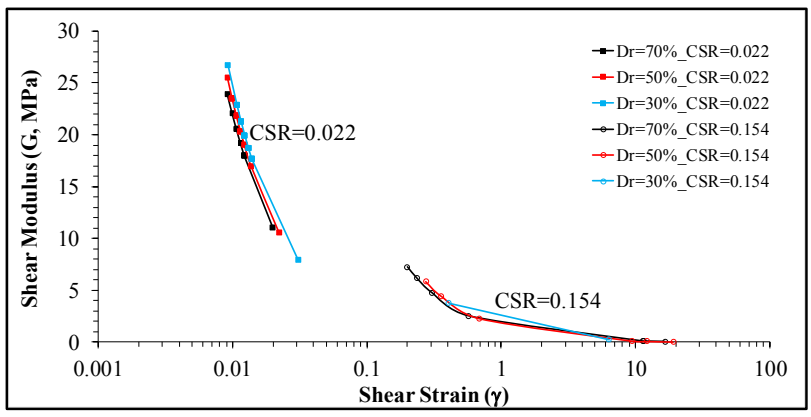

Fig. 6. Effect of relative density $\left(D_{r}\right)$ on shear modulus-shear strain relationship at different $\mathrm{CSR}$ levels a) $\mathrm{CSR}=0.022 \mathrm{~b}$ ) $\mathrm{CSR}=0.154$

Figure 7 presents the relationship among damping ratio (which was calculated using Eq. 3) versus shear strain $(\gamma)$. All specimens initially exhibit a small-strain $(\gamma<0.01 \%)$ damping ratio of about $1-9 \%$. With increasing shear strain, as the friction among soil particles is mobilized, the amount of energy dissipated in each loading cycle increases. This is manifested in the cyclic triaxial test results as an increase of the area of the cyclic stress-strain loop in Figure 4 and hence soil damping ratio in Figure 7. Similar observations (increasing $D$ with $\gamma$ ) are reported by many other investigators [21-22].

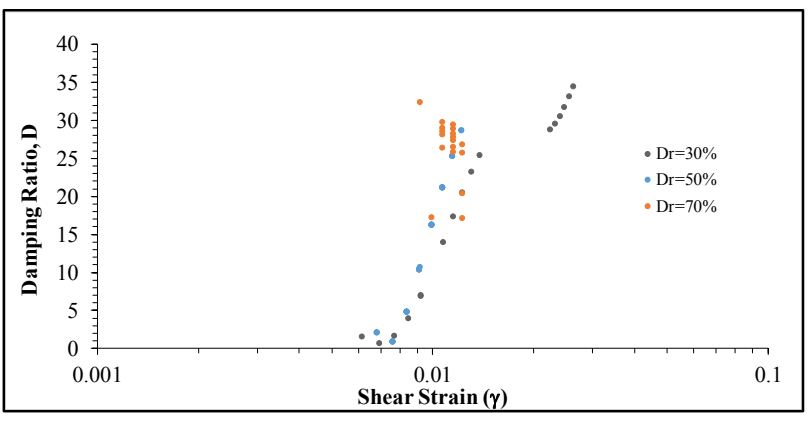

Fig. 7. Damping ratios for silt specimens at $\sigma_{0}^{\prime}=100 \mathrm{kPa}$

\section{Conclusions}

In this study, the results of cyclic triaxial tests performed on a nonplastic silt are reported. The study focuses on effect of various cyclic stress ratio (CSR) levels on behavior of specimens of different initial relative densities. The results revealed that, the influence of relative density and CSR on shear modulus and damping ratio are in agreement with previous findings in literature. As expected, regardless of CSR level, increase in shear strain causes a decrease in shear modulus. It was observed that the CSR is more effective at higher shear strains where its contribution on increasing shear modulus $(G)$ is highly pronounced. Effect of relative density on silt is similar to that on sand i.e. the increase in relative density causes an increase in shear modulus increases and a corresponding decrease in damping ratio.

\section{References}

1. JGS 0542-2000 (Method for Cyclic Triaxial Test to Determine Deformation Properties of Geomaterials)

2. N. Matasovic, M. Vucetic, Seismic Response of soil deposits composed of fully-saturated clay and sand layers, Proc., First International Conference on Earthquake Geotechnical Engineering, JGS, 611-616 (1995)

3. A. El Takch, A. Sadrekarimi, H. El Naggar, Dynamic Behaviors of Silt and Sandy Silt Soils Determined from Cyclic Ring Shear Tests, 3rd International Conference on Performance-based Design in Earthquake Geotechnical Engineering (Vancouver, 2017)

4. H.B. Seed, I.M. Idriss, Soil Moduli and Damping Factors for Dynamic Response Analysis, Report EERC 70-10, Earthquake Engineering and Research Center, University of California (Berkeley,1970)

5. T. Kokusho, Y. Yoshida, Y. Esashi, Dynamic Properties of Soft Clay for Wide Strain Range, Soils and Foundations, 22, 1-18 (1982)

6. H. B. Seed, T. Wong, I.M. Idriss, K. Tokimatsu, Moduli and Damping Factors for Dynamic Analysis of Cohesionless Soils, J. Geotechn. Eng., ASCE, 112, 1016-1032 (1986)

7. M. Vucetic, R. Dobry, Effect of Soil Plasticity on Cyclic Response, J. Geotechn. Eng., ASCE, 117, 89107 (1991)

8. T. Iwasaki, F. Tatsuoka, Y. Takagi, Shear Moduli of Sands Under Cyclic Torsional Shear Loading, Soils Found., 18, 39-56 (1978)

9. B.O. Hardin, V.P. Drnevich, Shear Modulus and Damping in Soils: Measurement and Parameters Effects, J. Soil Mech. Found. Div., ASCE, 98, 603624 (1972a)

10. B.K. Maheshwari, S.S. Kale, A.M. Kaynia, Dynamic Properties of Solani Sand at Large Strains: A Parametric Study, Int. J. Geotech. Eng., 6, 353-358 (2012) 
11. B.K. Maheshwari, A.K. Patel, Effects of Non-Plastic Silts on Liquefaction Potential of Solani Sand, J. Geotech. Geol. Eng., 28, 559-566 (2010)

12. P. Muley, B.K. Maheshwari, D.K. Paul, Effect of Fines on Liquefaction Resistance of Solani Sand, Proc. 15th World Conf. on Earthquake Eng. (Lisbon, Portugal. Paper No. 1484, 2012)

13. H. Y. Fang, R. C. Chaney, N. S. Pandit, Dynamic Shear Modulus of Soft Silt, International Conferences on Recent Advances in Geotechnical Earthquake Engineering and Soil Dynamics, 11 (1981)

14. G. Chen, B. Wang, J. Liu, Dynamic Shear Modulus and Damping Ratio of Recently Deposited Soils in the Coastal Region of Jiangsu Province, Geotechnical Engineering for Disaster Mitigation and Rehabilitation, Springer (Berlin, Heidelberg, 2008)

15. M. El Mosallamy, T. Tarek, A. El Fattah, M. El Khouly, Experimental study on the determination of small strain-shear modulus of loess soil, HBRC Journal, 12, 2,181-190 (2016)

16. H. D. Hsiao, V.T.A. Phan, Effects of silt contents on the static and dynamic properties of sand-silt mixtures, Geomech. Eng., 7, 3, 297-316 (2014)

17. ASTM D4253-16, Standard test methods for maximum index density and unit weight of soils using a vibratory table, ASTM International (West Conshohocken, PA, 2016)

18. JGS 0520-2000, Preparation of Soil Specimens for Triaxial Tests.

19. JGS 0541-2000, Method for Cyclic Undrained Triaxial Test on Soils.

20. N. Tanrınıan, E. Karakan, A. Sezer, S. Altun, Behavior of a dense nonplastic silt under cyclic loading, Eskisehir Tech. Univ. J. of Sci. Techn. BTheoretical Sci., 6, Special Issue, 183-191 (2018)

21. M. Vucetic, G. Lanzo, M. Doroudian, Damping at small strains in cyclic simple shear test, J. Geotech. and Geoenv. Eng., ASCE, 124, 7, 585 - 594 (1998)

22. J. Zhang, R. D. Andrus, C. H. Juang, Normalized shear modulus and material damping ratio relationships, J. Geotech. Geoenv. Eng., ASCE, 131, 4, $453-464$ (2005). 